\title{
都市空間の最適拡大過程
}

\author{
藤田昌 久* \\ I は じめに
}

計画にあたって，短期的効率性を追うあすり長期的効率性を見失わないように，といらこと を我が国の先人達は「急がば回れ」といら言葉で教えてくれている。たとえば経済成長理論に おいて有名なターンパイク定理は経済計画に打ける急がば回れの垈表的な例であるが，空間計 画に当ってもこのことは重要であると思われる。たとえば，短期的には非常にむだと思える $100 \mathrm{~m}$ 道路の終戦直後の名古屋市における建設は, 都市計画において急がば回れを実行した 1 例である。しかしながら，この名古屋市における 1 例は最近の我が国の都市計画においては例 外に属するものであり，逆に都市計画に扣ける長期的視野の欠除の結果が長期にわたる都市膨 張過程で蓄積されてきたものが今日の大都市における混乱の大きな要因を成していると考えら れる。このような観点に立ち, 本研究は空間計画にお打る長期的視野の重要性を, 都市空間の 最適拡大過程の簡単な数理モデルを用いて研究しよらとするものである。

問題は, 各種の都市施設より成る 1 点中心型の都市において, 将来の各年度における各施設 の都市全体における必要量が外生的に時系列として与えられたとき, 計画期間全体において都 市全体から得られる便益の合計が最大となるよらに，各年度において各施設の建設量を各地区 に対して配分決定することである1)。まずこの問題を数学的に定式化し，その問題の最適解の ための必要十分条件を最大原理を応用して求め, 各条件の経済学的意味について述べ。つ ぎに, 最適拡大過程の一般解を施設数が二つの場合について求め, その拡大過程に対応する地 価の空間的, 時間的変化について分析する。最後にそれらの結果を施設数が任意の個数の場合 へ拡張する。

\section{II 都市施設配置の最適問題}

以下のように単純化されたひとつの都市を想定する。この都市は全体として $\mathrm{n}$ 地区より成

* 京都大学交通土木工学科

† 本稿は 1973 年度地域学会での報告のうち, 紙数の都合上都市の再開発を考慮しない場合における部分に ついて加筆修正したものである。本研究をまとめるにあたり，大石，坂下両教授をはじめ多くの方々に 有益な御助言をいただいたことに対して感謝の意を表したい。もちろん，本報告におけるありうへき一 切の誤謬については筆者の責任であることはいうまでもない。

1）再開発をも考虑した場合の分析については参考文献 [3] を参照されたい。 
り, $d_{l}$ および $s_{l}$ を第 $l$ 番目の地区の都心からの距離および面積とし，次のように仮定する。

$$
\begin{aligned}
& d_{1}<d_{2}<\cdots<d_{l}<\cdots<d_{n} \\
& 0<s_{l}<\infty, l=1,2, \cdots, n-1, \quad s_{l}=\infty
\end{aligned}
$$

一方, 都市は $m$ 種類の施設から成っているとし，これらを $i=1,2 ， \cdots, m$ で示す。たと えば $i=1$ は業務用オフィス, $i=2$ は商業用オフィス, $i=3$ 以降は各種住宅などと考えるこ とができるであろう。この問題で対象とする計画期間を $[0, T]$ とし, 計画期間の各時刻 $t$ に おけける各施設の都市全体での必要量は $D_{i}(t)$ [個]として外生的に与えられているものと仮定 する。よって $x_{i l}(t)$ を時刻 $t$, 地区 $l$ に扣ける施設 $i$ の量とすると次の条件がみたされている 必要がある。

$$
\sum_{l} x_{i l}(t)=D_{i}(t)
$$

この条件は時間 $t$ による微分記号“.”を用いて次のように表わすこともできる。

$$
\sum_{l} \dot{x}_{i l}(t)=\dot{D}_{i}(t)
$$

$x_{i l}(t)$ 、地区 $l$ に施設 $i$ を建設することにより増加し, $u_{i l}(t)$ を地区 $l$, 時刻 $t$ における施設 $i$ の建設量[個／時間]とすると次の関係にある。

$$
\dot{x}_{i l}(t)=u_{i l}(t), \quad u_{i l}(t) \geqq 0
$$

つぎに, 各施設の 1 単位要にする敷地面積は一定とし, これらを $k_{i}$ [面積 $/$ 個], $\left(k_{i}>0\right)$ で 示す。すると，各地区では次の面積制約が満たされていなければならない。

$$
\sum_{i} k_{i} x_{i l}(t) \leqq s_{l}
$$

いっぽう，計画に拈ける評価要因としては，施設の建設に要する費用と建設された施設から 得られる便益とが考えられる。各施設 1 単位建設に要する費用は，地区間において差はないと

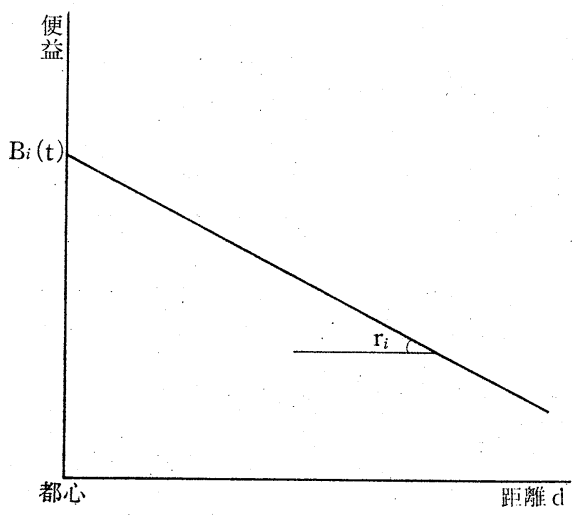

囝 1 施設便益の距離に対する変化 
し， $b_{i}(t)$ [円／個]で示す。次に，各施設の 1 単位から得られる便益は，図 1 に示すように, 都心で最大でこれを $B_{i}(t)$ と拉き, 都心からの距離とともに $r_{i}$ の勾配で減少するものと仮定 する2)。各施設から得られる便益は相互比較可能であるとし，統一単位として[円／個・時間] を用いる。よって本研究にお护る計画目的として, 計画期間全体にわたって施設全体から得ら れる便益の合計からそれらの施設の建設に要する費用をさし引いた值である，次の関係を最大 化することにする。

$$
\int_{0}^{T} \rho(t) \sum_{l=1}^{n} \sum_{i=1}^{m}\left[\left(B_{i}(t)-r_{i} d_{l}\right) x_{i l}(t)-b_{i}(t) u_{i l}(t)\right] d t
$$

ここに $\rho(t)$ は便益の時間的ウエイト関数で以下のように仮定する。

$$
\rho(t=0)=1, \rho(t)>0,0 \leqq t \leqq T
$$

なお本研究では, 現在までの大都市の経過からして, 都市がたえず成長して行く場合に注目 しているので次のように仮定しておく。

$$
\dot{D}_{i}(t) \geqq 0,0 \leqq t \leqq T, \text { for all } i
$$

以上より本研究で考察する都市空間の最適拡大過程の問題は次のように定式化される。

\section{問 題 $\mathbf{A}$}

計画期間全体における都市の純便益の合計

$$
\int_{0}^{T} \rho(t) \sum_{i} \sum_{l}\left[\left(B_{i}(t)-r_{i} d_{l}\right) x_{i l}(t)-b_{i}(t) u_{i l}(t)\right] d t
$$

を以下の制約のもとに最大化する建設速度 $u_{i l}(t),(i=1,2, \cdots, m, l=1,2, \cdots, n, 0 \leqq$ $t \leqq T$ ) を求めよ。

a）施設量变化式

$$
\begin{aligned}
& \dot{x}_{i l}(t)=u_{i l}(t) \\
& u_{i l}(t) \geqq 0
\end{aligned}
$$

b）施設量制約

$$
\sum_{l} u_{i l}(t)=\dot{D}_{i}(t)
$$

c）面積制約

$$
\sum_{i} k_{i} x_{i l}(t) \leqq s_{l}
$$

d）初期条件

$$
\left.x_{i l}(0)=0^{3}\right)
$$

2）この仮定は文献 [1] におけるアロンゾの仮定と類似のものであるが，各施設間の直接の相互依存関係を 考えれば繁密には妥当しないかもしれない。しかし単純化のためにこの仮定を現実の第一次近似とみな して採用する。

3）施設の破壊をここでは考慮していないので初期条件をこのようにおいても問題の一般性は失なわれない。 
ただし以上の問題において $B_{i}(t) ， \dot{D}_{i}(t)$ および $\rho(t)$ は時間 $t$ に関して連続と仮定する。ま た記号 $\Sigma$ は, $i$ についは $i=1$ から $m$ までの和, $l$ については $l=1$ から $n$ までの和とし， 以下同様とする。

この問題は要するに, 各時刻において外生的に与えられた各施設の都市全体での必要増加分 を，計画期間に拈ける便益の合計が最大となるように各地区に面積制約をみたしながら配分・ 建設して行くことである。なお，以下の分析において，単位敷地面積当りの施設 $i$ から得られ る便益の距離に対する減少勾配である， $r_{i} / k_{i}$ の值が重要となるが，施設の番号付けは任意であ るので次のよらに仮定しておく。

$$
r_{1} / k_{1}>r_{2} / k_{2}>\cdots>r_{i} / k_{i}>\cdots>r_{m} / k_{n}>0
$$

李た，以下の便宜のために次のように定義された“留積ウエイト関数” $\sigma(t)$ を導入して掠 $<。$

$$
\sigma(t)=\int_{0}^{t} \rho(\tau) d \tau
$$

なお，計画対象期間の長さ $T$ は当分の間有限の大きさと仮定しておくが，IV-3 において無 限大の場合へ拡張する。

以上のよらに定式化された問題 $\mathrm{A}$ は, いわば normative に動学化された von Thünen モデ ルと解することができるであろゔ)。

\section{III 最適条件とその経済学的解釈}

問題 $\mathrm{A}$ に対する最適条件は最大原理を用いて次のようにまとめられる5)。

\section{最適条件 $\mathbf{A}$}

関数 $H$ および $L$ を次のように定義する。

$$
\begin{aligned}
H(x, u, \phi, p, t) & =\sum_{i} \sum_{l} \rho(t)\left(B_{i}(t)-r_{i} d_{l}\right) x_{i l} \\
& +\sum_{i} \sum_{l}\left(\phi_{i l}-\rho(t) b_{i}(t)-k_{i} p_{l}\right) u_{i l} \\
L & (x, u, \varphi, p, q, t)=H+\sum_{i} q_{i}\left(\sum_{i} u_{i l}-\dot{D}_{i}(t)\right)
\end{aligned}
$$

そうすると， $u_{i l}(t)$ が問題 $\mathrm{A}$ に拈ける最適建設過程であるためには，以下の条件を満たす 関数 $x_{i l}(t), \phi_{i l}(t), p_{l}(t)$ および $q_{i}(t)$ が存在することが必要十分である。

4) 式 $(2.5)$ 亿おける $\left(B_{i}(t)-v_{i} d_{l}\right)$ を, 需要者の施設 $i$ 亿対するレントの付㥀曲線を解し，問題 A t 市場均衡による都市空間の均衡拡大過程を求めるための便宜的な手段としてみなし, positive な動学的 地価理論の方向へ議論を発展させることもできる。それについては文献 [5]を参照。

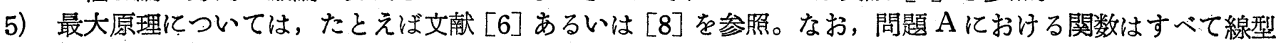
であるので，以下の条件は最適解のための必要条件であるとともに十分条件でもある。このことについ ては参考文献 [2] と [7] を参照。式 (3.1) で定義される関数 $H$ は普通のハミルトニアン関数に状態制 約 (2.9) 飞対応する項が加わったものである。また，(3.2) とる $L$ は， $H$ を(2.6) と (2.8) 飞従っ て最大化する際のラグランジエ関数である。 
(i) $\dot{x}_{i l}(t)=u_{i l}(t)$

(ii) $H(x(t), u(t), \varphi(t), p(t), t)$

$$
=\max \left\{H(x(t), u, \varphi(t), p(t), t) \mid \sum_{l} u_{i l}=\dot{D}_{i}(t), u_{i l} \geqq 0\right\}
$$

(iii) $\dot{\varphi}_{i l}(t)=-\partial L / \partial x_{i l}(t)=-\rho(t)\left(B_{i}(t)-r_{i} d_{l}\right)$

(iv) $\partial L / \partial u_{i l}=\phi_{i l}(t)-\rho(t) b_{i}(t)-k_{i} p_{l}(t)+q_{i}(t) \leqq 0$ for all $i$ and $l$

$$
\boldsymbol{\phi}_{i l}(t)-\rho(t) b_{i}(t)-k_{i} p_{l}(t)+q_{i}(t)=0 \text { when } u_{i l}(t) \geqq 0
$$

(v) $\sum_{l} u_{i l}(t)=\dot{D}_{i}(t)$

(vi) $\dot{p}_{l}(t) \leqq 0$

$$
\dot{p}_{l}(t)=0 \text { when } \sum_{l} k_{i} x_{i l}(t)<s_{l}
$$

(vii) $H(x(t), u(t), \varphi(t), p(t), t)$ は $t$ に関して連続である。

(viii) $x_{i l}(0)=0$

$$
\begin{aligned}
& \phi_{i l}(T)=0 \\
& p_{l}(T)=0
\end{aligned}
$$

以上の最適条件を経済学的に解釈 するために, 目的関数に打ける $\left(B_{i}(t)-r_{i} d_{l}\right)$ を, 地区 $l$ に拈ける施設 $i$ の 1 単位に対して時刻 $t$ に支払われるレント〔円／時間・個〕であり， $\rho(t)$ を 将来収益の初期時刻 $t=0$ に対する割引関数であるとしてみよう。そうすると, 時刻 $t$, 地区 $l$ に建設される単位施設 $i$ から得られる将来収益の現在価值 $\phi_{i l}(t)$ は次のように計算される。

$$
\phi_{i l}(t)=\int_{t}^{T} \rho(\tau)\left(B_{i}(\tau)-r_{i} d l\right) d \tau
$$

上式の両辺を $t$ で微分すると（3.4）となり, 結局 (3.4) は各施設から得られる将来収益の 時間的変化を与える式であることがわかる，また，(3.13）に $t=T$ を代入すると (3.11) を得

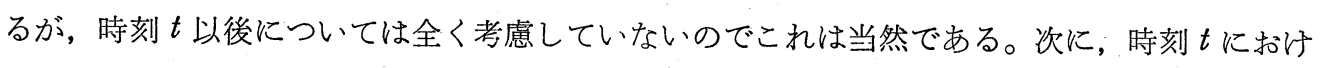
る地区 $l$ の地価を $P_{l}(t)$ で表わすと, 次式で定義され $p_{l}(t)$ は初期時刻に割引かれた地価とな る。

$$
p_{l}(t)=\rho(t) P_{l}(t)
$$

したがって, 時刻 $t$, 地区 $l$ に施設 $i$ を 1 単位建設・供給しようとする業者にとってのその

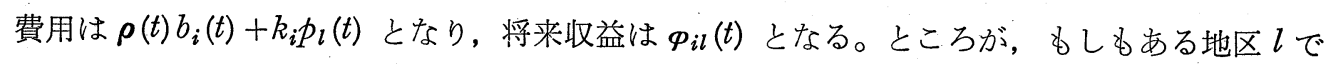
$\boldsymbol{\phi}_{i l}(t)>\rho_{i}(t) b_{i}(t)+k_{i} p_{l}(t)$ となれば, 施設 $i$ は時刻 $t$ この地区において無限大のスピードで建設 される。つまり $u_{i l}(t)=\infty$ となる。一方, 施設 $i$ にいてみたときもしもすべての地区で $\phi_{i l}(t)$ $<\rho(t) b_{i}(t)+k_{i} p_{l}(t)$ となっているならば, 施設 $i$ はどこにも建設されない, つまり, $u_{i l}(t)=$ 0 for all $l$ となる。このいずれの場合においても (2.8) で要求されている施設 $i$ の建設供給制 約はみたされない。したがって,この供給制約を満足させるために, 公共体が施設 $i$ の 1 単位 建設に対して $q_{i}(t)$ の建設補助金 [円／個]を出すものとすると，これは次の条件をみたすよ 
らに決められなければならない。

$$
\left.\begin{array}{l}
\phi_{i l}(t)+q_{i}(t) \leqq \rho(t) b_{i}(t)+k_{i} p_{l}(t) \text { for all } l \\
\phi_{i l}(t)+q_{i}(t)=\rho(t) b_{i}(t)+k_{i} p_{l}(t) \text { for at least one } l \text { when } \dot{D}_{i}(t)>0
\end{array}\right\}
$$

（3.7）を考光れば,上の条件は（3.5)・(3.6) に一致することがわかる。つまり(3.5)・(3.6) は施設の供給業者に対する non-profit の条件であることがわかる。また，(3.1）で定義される $H$ の右辺の第 1 頃は変数 $u_{i l}$ を含んでいないので, 結局, (3.3) で要求されている条件は, 施 設の供給業者全体における利潤最大化行動を表わすものであることもわかる。

いっぽう土地市場に打ける均衡であるが，時刻 $T$ 以降についてはだれも一切考慮しないと 仮定しているので, 時刻 $T$ 以降における土地から収益を期得するものはいず, $p_{l}(T)=0$, つ まり（3.12）となるはずである。また，割引かれた均衡地価 $p_{l}(t)$ が途中で上昇することは ありえない。なぜなら, そのときは地価 $p_{l}(t)$ の上昇期の始めにその土地を買い, 下降期の最 初に売ることにより投機利純を得ることができるので, それは均衡地価ではありえない。よっ て，(3.8）は均衡地価 $p_{l}(t)$ のみたすすべきとつの条件であることがわかる。

逆に, 割引きされた均衡地価 $p_{l}(t)$ がその地区に空地を有している間に下降することはあり 得ない。なぜなら，そのときは，その空地を持っている地主は下降期のはじめにそれを手ばな した方が得であるが，だれもその土地をその価格で買らものは存在しない。よってその地価は 均衡市場価格でなかったことになる。よって，均衡地価は（3.9）も満たしているはずである。

以上より，最適条件 A は，公共体が問題 $\mathrm{A}$ の最適拡大過程を競争市場を通じて実現しよう とした時の市場均衡条件をあらわしているものと解釈できることがわかる。その場合， $\boldsymbol{q}_{i l}(t)$ は各施設の将来収益, $p_{l}(t)$ は地価, $q_{i}(t)$ は建設補助金（ただし，いずれも初期時刻に割引か れた值)を表わす。ただし条件（vii）は数学的条件である。

\section{IV 最適拡大過程（施設数 $\boldsymbol{m}=\mathbf{2}$ )}

以上の最適条件を用いて問題 $A$ の解を求めるわけであるが，説明を容易にするためにすず 施設数 $m=2$ の場合についてここで解を求める。たとえば, $i=1$ はオフィスで $i=2$ は住宅と 考えれば適当であろう。あるいは $i=1$ を高層住宅， $i=2$ を平屋住宅と考学ることもできる。 一般解を求めたのち, その一般解の問題 A における各パラメータによる比較分析を行う。ま た, 最適拡大過程にともなった地価の変動について最後にまとめて述べる。なお, 任意の施設 数の場合への一般化は次節で行う。

\section{VI-1 最適拡大過程の一般解}

$m=2$ に限定しても問題 $\mathrm{A}$ は $2 n$ 個の状態変数を有しているので, その一般解を演釈的に求 めるにはかなりの手数を要する6)。よってここでは逆に次の方法をとる。 


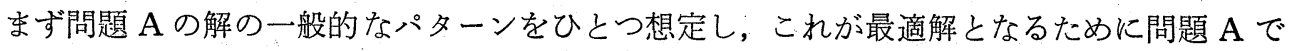
与えられたパラメータのみたすべき一般的な必要十分条件を最適条件 $\mathrm{A}$ を用いて求める。次 に仮定（2.1)〜 (2.4） および（2.11）をみたすどんな 1 組のパラメータもその一般的な必要十 分条件のいずれかひとつのパターンになっていることを示す。そらすれば最適条件 A は最適 解のための必要十分条件であるから, 次の解の唯一性に関する補助定理からして, 我々は問題 A の完全な一般解を求めたことになる。

補助定理〔解の唯一性〕仮定（2.1）〜 (2.4) 抽び（2.11）のもとでは, 問題 A の解は存 在するとすれば唯ひとつである。

証明：まずはじめに, 最適解においては, どんな同一の施設 $i$ も有限大の時間区間の間, 同 時に 2 つ異なる地区に建設されていることはないことに注目しよう。なぜなら，もしもかり に地区 $l$ と $l^{\prime}$ に建設されているとするならば (3.6) より， $\phi_{i l}(t)-k_{i} p_{l}(t)=\phi_{i l^{\prime}}(t)-k_{i} p_{l^{\prime}}(t)$

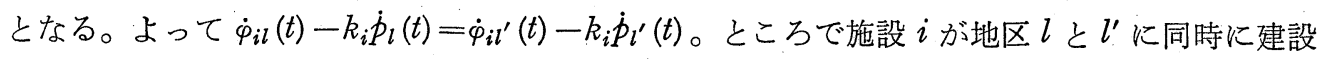
されているのだから，それらの地区には空地が残っているはずであり，よって (3.9)より $\dot{p}_{l}(t)=\dot{p}_{l^{\prime}}(t)=0$, つまり $\dot{\varphi}_{i l}(t)=\dot{\varphi}_{i l^{\prime}}(t)$ ，となり，(3.4) より結局 $d_{l}=d_{l^{\prime}}$ となる。以上のこと より，最適解に打ける $u_{i l}(t)$ は必ず 0 か $\dot{D}_{i}(t)$ のどちらかの值しかとらないことがわかる。

つぎに, $\left\{u_{i l}{ }^{*}(t)\right\}$ と $\left\{\hat{u}_{i l}(t)\right\}, i=1,2, \cdots, m, l=1,2, \cdots, n, t=0 \sim T$, を異なる二つの 解としよう。そうすると, いずれがの有限大の時間区間の間, $u_{i l} *(t) \neq \hat{u}_{i l}(t)$ と, いずれかの 組 $(i, l)$ についてなっているはずである。ところが上に求めた結果より, これは $u_{i l} *(t)=$ $\dot{D}_{i}(t), \hat{u}_{i l}(t)=0$ あるいは $u_{i l} *(t)=0, \hat{u}_{i l}(t)=\dot{D}_{i}(t)$ を意味する。ところで, 問題 $\mathrm{A}$ の各式 は完全に線型であるので, 任意の $\alpha(1>\alpha>0)$ に関して, $\left\{\tilde{u}_{i l}(t)\right\}=\alpha\left\{u_{i l} *(t)\right\}+(1-\alpha)$ $\left\{\hat{u}_{i l}(t)\right\}$ もまた解である。したがって, 問題の時間区間において $\tilde{u}_{l}(t)=\alpha u_{i l} *(t)+(1-\alpha) u_{i l} *$ $(t)$ となる。結局, 最適解 $\left\{\tilde{u}_{i l}(t)\right\}$ においては $0<\tilde{u}_{i l}(t)<\dot{D}_{i}(t)$ となる時間区間が存在するこ とになるが，これは最初に求めたことに矛盾する。よって解は存在するとすれば唯一しかない はずである。

最適拡大過程の一般的なパターンとして次のように想定する。

(1) $r_{i} / k_{i}$ (つまり, 単位敷地面積当りの施設便益の距離に対する低減勾配) のより小さい施

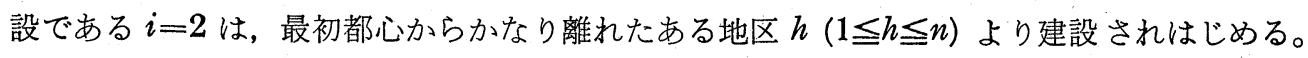
その後地区 $h$ の 1 部, $h+1$ の 1 部, $h+2$ の 1 部之, 各地区に相当量の空地を残しながら順次 効外に向って, ある地区 $k-1(h \leqq k \leqq n)$ まで同様に建設されて行き, 計画期間の最後に地区 $k$ に致る。

6）この方法も実際可能であり，それについては文献 [4]を参照。 
（2）一方, 低減勾配 $r_{i} / k_{i}$ のより大きな施設である $i=1$ は, 最初都心に一番近い地区 1 よ り建設されはじめる。その後地区 2 , 地区 3 と順次郊外に向って各地区を地区 $h-1$ まで $i=1$ でらめつくして行く。その後は $i=2$ の建設のあとに残された各地区の空地を順次郊外に向っ てうめつくして行き, 最後に地区 $k$ に致る。

以上の最適拡大過程を描いたものが図 2 である。

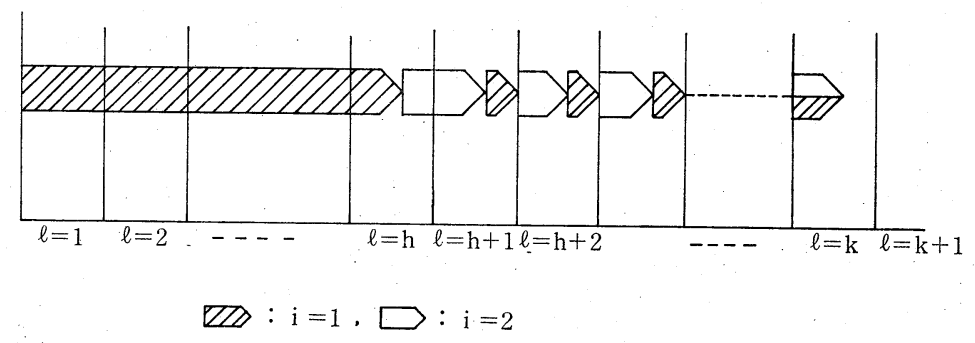

図 2 最適拡大過程 $(m=2)$

まず，このように想定された拡大過程が問題 $\mathrm{A}$ の最適解となりらるための必要条件を，問 題に扣けるパラメータ $T, \rho(t), B_{i}(t), r_{i}, b_{i}(t), k_{i}, d_{l}, D_{i}(t)$ および $s_{l}$ の関係として求め よう。このために, 施設 $i$ の建設が地区 $l$ から $l+1$ に移る時刻を $t_{i l}{ }^{*}$ と打くと, 上述の想定 された拡大過程に従えばこれらは次の関係にある。

$$
\left.\begin{array}{l}
\begin{array}{l}
0<t_{11} *<t_{12} *<\cdots<t_{1 h-1} *<t_{1 h} *<t_{1 h+1} *<\cdots<t_{1 k-1} *<T \\
t_{10}{ }^{*} \equiv 0, t_{1 l} * \equiv T \text { for } l \geqq k \\
0<t_{2}{ }^{*}<t_{2 h+1} *<\cdots<t_{2 k-1}<T
\end{array} \\
t_{2} l^{*} \equiv 0 \text { for } 0 \leqq l \leqq h-1, t_{2} l^{*} \equiv T \text { for } l \geqq k \\
t_{1} l^{*}>t_{2} l, l=h, h+1, \cdots, h-1
\end{array}\right\}
$$

これらの $t_{i l} *$ を用いて想定された建設計画は次のように表わせる。

$$
u_{i l}(t)=\left\{\begin{array}{c}
\dot{D}_{i}(t), t_{i l-1}{ }^{*} \leqq t \leqq t_{i l} * \\
0, \text { その他の時 }
\end{array}, i=1,2, l=1,2, \cdots, n\right.
$$

我々のここでの課題は, まず $t_{i l}$ * の值および地区 $h$ とを問題におけるパラメータから正 確に求めることであるが，このために $t_{1 l}{ }^{0}$ を次のように定義する。

$$
\begin{aligned}
& k_{1} D^{1}\left(t_{1 l}{ }^{0}\right)=\sum_{j=1}^{l} s_{j}, l=1,2, \cdots, n, t_{10}{ }^{0} \equiv 0 \\
& t_{1 l^{0}}=\infty \text { when } k_{1} D_{1}(T)<\sum_{j=1}^{l} s_{j}
\end{aligned}
$$

そうすると，想定より $t_{1 l} *$ の 1 部は次のように定まる。

$$
t_{1 l}^{*}=t_{1 l} l^{0}, l=0,1,2, \cdots, h-1
$$


また，想定より $k$ は次の関係を満たす地区として一義的に定まる。

$$
\sum_{j=1}^{k-1} s_{j}<\sum_{i} k_{i} D_{i}(T) \leqq \sum_{j=1}^{k} s_{j}
$$

一方, 想定された拡大過程のもとでは,

$$
\sum_{i} k_{i} D_{i}\left(t_{i l}{ }^{*}\right)=\sum_{j-1}^{l} s_{j}, j=h, h+1, \cdots, k-1
$$

となるはずであり, これが (4.6) で決まる以外の $t_{i l}{ }^{*}$ を求めるための半分の関係式を与えて くれる。関係式の残りの半分は最適条件 A こおいて, この想定された拡大過程に対応する補 助変数の関係より以下のように求まる。まず，最適条件 $\mathrm{A}$ の（vii）で要求される関数 $H(t)$ の連続性より, 各 $t_{i l}{ }^{*}$ において次の条仲が満たされている必要がある?。

$$
\begin{aligned}
& \phi_{i l}\left(t_{i l} *\right)-\rho\left(t_{i l}^{*}\right) b_{i}\left(t_{i l}{ }^{*}\right)-k_{i} p_{l}\left(t_{i l}{ }^{*}\right) \\
&=\phi_{i l+1}\left(t_{i l}{ }^{*}\right)-\rho\left(t_{i l}{ }^{*}\right) b_{i}\left(t_{i l}{ }^{*}\right)-k_{i} p_{l+t}\left(t_{i l} *\right) \\
& l=1,2, \cdots, k-1 \text { for } i=1, l=h, h+1, \cdots, k-1 \text { for } i=2
\end{aligned}
$$

一方, 想定された拡大過程 (4.4) のもとでは

$$
\sum_{i} k_{i} x_{i j}(t)<s_{j}, \text { for } 0 \leqq t<t_{1 l} *, l \leqq j \leqq n
$$

となるから，(3.9) より次の結果が得られる8)。

$$
p_{j}(t)=p_{j}(0) \text { for } 0 \leqq t \leqq t_{1 l} *, l \leqq j \leqq n
$$

ところで (4.3) より $t_{1}{ }^{*}>t_{2 l}{ }^{*}$ であるから, 結局 (4.9) と（4.11）より次の関係が得られ る。

$$
\begin{gathered}
\left(\varphi_{1 l}\left(t_{1 l} *\right)-\varphi_{1 l+1}\left(t_{1 l}^{*}\right)\right) / k_{1}=p_{l}(0)-p_{l+1}(0), l=1,2, \cdots, h-1 \\
\left(\varphi_{1 l}\left(t_{1 l} *\right)-\varphi_{1 l+1}\left(t_{1 l} *\right)\right) / k_{1}=\left(\phi_{2 l}\left(t_{2 l}{ }^{*}\right)-\phi_{2 l+1}\left(t_{2 l}{ }^{*}\right)\right) / k_{2} \\
=p_{l}(0)-p_{l+1}(0), l_{l}=h, h+1, \cdots, k-1
\end{gathered}
$$

一方，(3.4）と（3.11）より $\phi_{i l}(t)$ は次のよう に定まる。

$$
\phi_{i l}(t)=\left(B_{i}(t)-\gamma_{i} d_{l}\right)(\sigma(T)-\sigma(t))
$$

ここに $\sigma(t)$ は (2.12) で定義される留積ウエイ ト関数である。よって将来収益関数 $\varphi_{i l}(t)$ は図 3 のよらに描ける。

(4.14）を(4.12) と（4.13）に代入して次の関

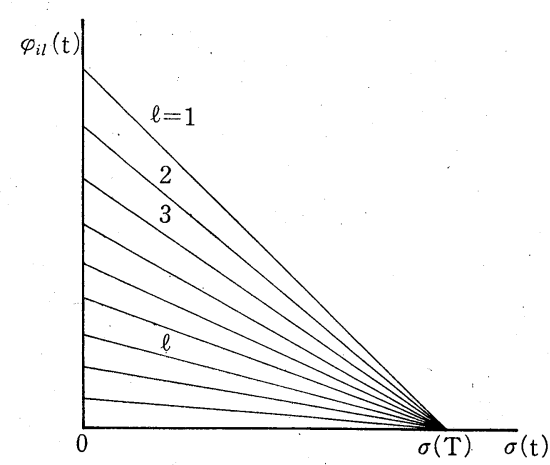

図 3 将来収益関数 $\Phi_{i l}(t)$ の変化

7）なぜなら，我々は $\rho(t)$ および $\dot{D}_{i}(t)$ を連続関数と仮しており， $u_{i l}(t)$ は $(4.4)$ と想定されているから。

8） (3.4) より $\Phi_{i l}(t)$ は $t$ に関して連続であるので, (4.9) より $p_{l}\left(t_{1} l_{-}\right)=p_{l}\left(t_{1} l+{ }^{*}\right)$ となることに注意。 
係をらる。

$$
\begin{aligned}
& p_{l}(0)-p_{l+1}(0)=\left(d_{l+1}-d_{l}\right)\left(\sigma(T)-\sigma\left(t_{1 l} *\right)\right) r_{1} / k_{1}, l=1,2, \cdots, h-1 \\
& p_{l}(0)-p_{l+1}(0)=\left(d_{l+1}-d_{l}\right)\left(\sigma(T)-\sigma\left(t_{1 l} *\right)\right) r_{1} / k_{1} \\
& =\left(d_{l+1}-d_{l}\right)\left(\sigma(T)-\sigma\left(t_{2 l} *\right)\right) r_{2} / k_{2}, l=h, h+1, \cdots, k-1
\end{aligned}
$$

(4.16)を整理して最終的に次の関係をうる。

$\left(\sigma(T)-\sigma\left(t_{1 l} *\right)\right) r_{1} / k_{1}=\left(o(T)-\sigma\left(t_{2 l} *\right)\right) r_{2} / k_{2}, l=h, h+1, \cdots, k-1$

結局 (4.8) と（4.17）で与えられる 2 元連立方程式を $k$ 一 $h$ 個解くことにより. 残りの $t_{i l}$ * $(i=1,2, l=h, h+1, \cdots, k-1)$ は完全に定まる。

ところで $i=2$ が最初に地区 $h$ に建設されるためには (3.3) より次の関係が満たされておく 心要がある。

$$
\begin{aligned}
\varphi_{2 l}(0) & -\rho(0) b_{2}(0)-k_{2} p_{l}(0) \leqq \varphi_{2 h}(0) \\
& -\rho(0) b_{2}(0)-k_{2} p_{h}(0), l=1,2, \cdots, h-1
\end{aligned}
$$

よって (4.12) と (4.14) にl=h-1 を適用し, 上式とより次の関係を得る。

$$
\left(\sigma(T)-\sigma\left(t_{1 h^{*}-1}\right)\right) r_{1} / k_{1} \geqq \sigma(T) r_{2} / k_{2}
$$

最後に，(4.5）と (4.8) より $t_{1 h^{0}} \geqq t_{1 h^{*}}{ }^{*},(4.6)$ より $t_{1 h-1}{ }^{*}=t_{1 h-1}{ }^{0}$ となるが，これらと (4.17) と (4.19) とより次の関係をらる。

$$
\sigma\left(t_{1 h-1}{ }^{0}\right) \leqq\left(1-\frac{r_{2}}{k_{2}} / \frac{r_{1}}{k_{1}}\right) \sigma(T) \leqq \sigma\left(t_{1 h}^{0}\right)
$$

以上，我々は最初に想定した拡大過程が最適であるための必要条件として，第 1 に (4.7) が 満たされ，第 2 に (4.5) で定義される $t_{1 h^{0}}$ が条件 (4.20) を満たし, 第 3 に連立方程式 (4.8), (4.17) の解として求まる $t_{i l}{ }^{*}(i=1,2, l=h, h+1, \cdots, k-1)$ と (4.6) で定まる $t_{1}{ }^{*}(l=0$, $1,2, \cdots, h-1)$ とが条件（4.1)〜 (4.3) を満たすこと，といら三つを得た。ところが，この 第 3 番目の条件は，第 1 と第 2 の条件が満たされている限り自動的にみたされているといらこ とが図 4 を用いて次のように確かめられる。図 4 の横軸および縦軸はそれぞれ $i=1$ のための 時刻 $t_{1}$ と $i=2$ のための時間 $t_{2}$ とを留積ウエイト関数 $\sigma(t)$ に比例してとったものである。こ の座標軸に扔いて, 関係式

$$
\sum_{i} k_{i} D_{i}\left(t_{i}\right)=\sum_{j=1}^{l} s_{j}, l=1,2, \cdots, k-1
$$

は右下りの曲線群として ${ }^{9)}$ また関係式

9）(4.21）が右下りの曲線群を与えることは，(4.21）を全微分し， $d \sigma\left(t_{1}\right) / d \sigma\left(t_{2}\right) \mid$ 曲線 $(4.21)=-k_{1} \dot{D}_{1}\left(t_{1}\right) \rho\left(t_{2}\right) / k_{2} \dot{D}_{2}\left(t_{2}\right) \rho\left(t_{2}\right)$ となり，これに仮定 $(2.3)$ と (2.4) を用いて知ることができる。ただし， $\dot{D}_{i}(t)=0$ の時間がある場合 には，四8ように描けるが本質的には図4とかわらない。 


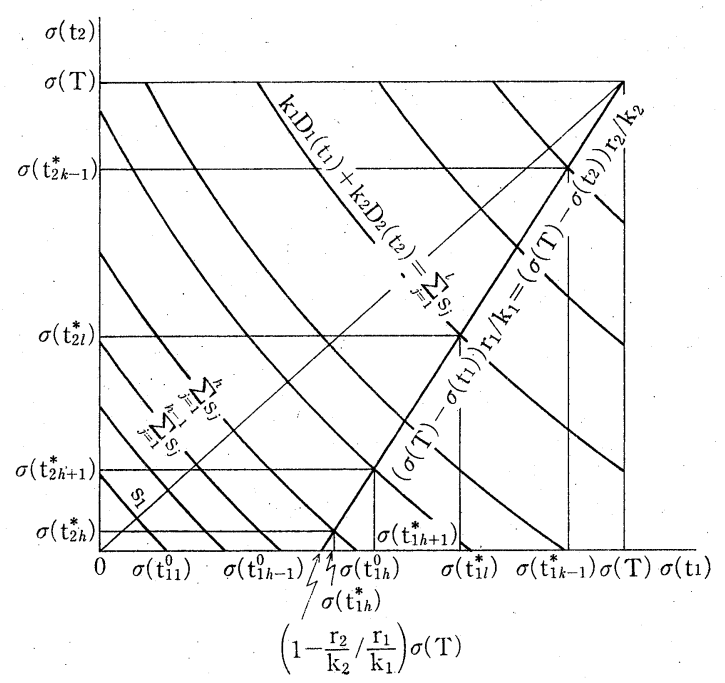

図4 建設スイッチ時刻 $t_{i l}$ * の決定 $(m=2)$

$$
\left(\sigma(T)-\sigma\left(t_{1}\right)\right) r_{1} / k_{1}=\left(\sigma(T)-\sigma\left(t_{2}\right)\right) r_{2} / k_{2}
$$

は左下りの直線として, それぞれ図 4 のよらに描ける。この図に扣いて, $t_{1 l}{ }^{\mathbf{0}}$ は横軸と曲線群 (4.21) の交点として, $t_{i l}$ * は直線 (4.22) と曲線群 (4.21) の交点として決まるが，条件 (4.7) と（4.20）が満たされているかぎりこれらは（4.1)〜 (4.3) をみたすことは図から容易に読み とれる。

以上により, 最初に想定された拡大過程が最適であるために問題 $\mathrm{A}$ におけるパラメータの みたすべき必要条件として最終的に（4.7）と（4.20）の二つを得た。逆に，もしもこの二つの 条件がみたされているならば，(4.5）と（4.6）で決まる $t_{1 l} *(l=1,2, \cdots, h-1)$ および (4.8) と (4.17) で定められる $t_{i l}{ }^{*}(i=1,2, l=h, h+1, \cdots, k-1)$ を用いて拡大過程 $u_{i l}(t)$ を (4.4) のように決めれば, 仮定（2.1）（2.4）および（2.11）のもとではこれは問題 A の最適 解となっていることが証明できる10)。なお，この最適拡大過程に対応する将来収益関数 $\boldsymbol{\phi}_{i l}(t)$ は（4.14）で与えられ，地优 $p_{l}(t)$ の变化は次のように与えられる。

$$
\dot{p}_{l}(t)=\left\{\begin{array}{l}
0 \text { for } t<t_{1 l} * \\
-\rho(t)\left(r_{1} / k_{1}\right)\left(d_{j}-d_{l}\right) \text { for } t_{1 j-1} * \leqq t<t_{1 j}{ }^{*}, j=l+1, l+2, \cdots, k-1
\end{array}\right.
$$

$$
p_{l}(T)=0, l=1,2, \cdots, n
$$

また地価の初期值は（4.15）と（4.16）のように定まる。この地価関数 $p_{l}(t)$ を図示したもの が図 5 である。これら地価の変化についてはVI-3でもら一度まとめてふれる。

10）この証明のためには，この $u_{i l}(t)$ を最適条件 $\mathrm{A}$ に代入し, 要求されている条件をすへてみたす補助変数 $\varphi_{i l}(t), p_{l}(t)$ および $q_{i}(t)$ が存在することを確かめればよいが, ここではその評細は省略する。 


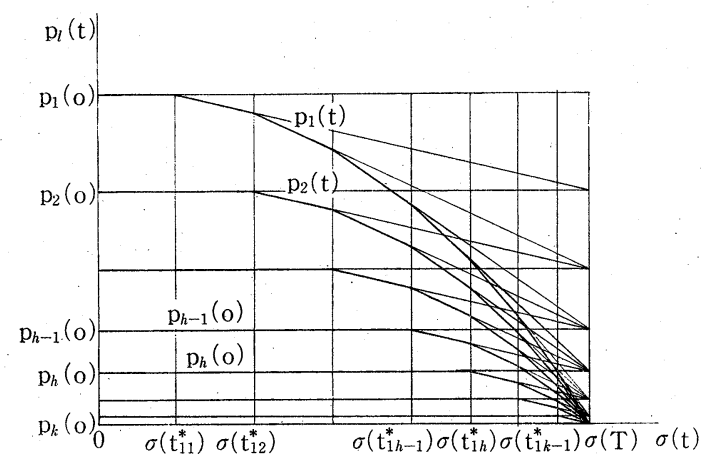

図 5 地価 $p_{l}(t)$ の時間的変化

最後に，仮定（2.1)〜 (2.4) および（2.11）ををみたす問題 A のどんな 1 組のパラメータが 与えられても, 条件 (4.7) と (4.20) をみたす地区の組 $(h, k), 1 \leqq h \leqq k \leqq n$ が常に唯一存在 することは (4.5) による $t_{11}{ }^{0}$ の定義より簡単に確かめられる。よって, そのような問題の最適 拡大過程は最初に想定したパターンとなる。

以上を次のようにまとめておこう。

定理 1 〔最適拡大過程, $m=2$ 〕仮定 $(2.1)$ (2.4) および（2.11）のもとでは問題 A の 最適拡大過程は唯ひとつ常に存在し，次のように与えられる。まず (4.7) により最終地区 $k$ が決り，(4.5）による $t_{1 l}{ }^{0}$ の定義を用いて (4.20)より最初に $i=2$ が建設されはじめる地区 $h$ が決る。そうすると，(4.5）と（4.6）で決まる $t_{1} l^{*}(l=1,2, \cdots, h-1)$ および (4.8) と (4.17) で定められる $t_{i l} *(i=1,2, l=h, h+1, \cdots, k-1)$ を用いて最適建設過程は (4.4) と して与えられる。な括, これに対応する施設の（割引された）将来収益関数 $\phi_{i l}(t)$ および（割 引された）地価 $p_{l}(t)$ はそれぞれ (4.14)，(4.23）と（4.24）で与えられる。

\section{VI-2 最適拡大過程の比較分析}

ここでは前節で求められた最適拡大過程の一般解が, パラメータの值の違いによってどのよ らに異なった拡大過程の形状をもたらすか，あるいはどのように変化するかを分析する。

まず，都市拡大過程の形状が施設の増加速度 $D_{i}(t)$ の值いかんによりどのように異なったも のになるかを，大きく次の二つの場合に分けて見てみよう。

(a) $\dot{D}_{i}(t)>0$ for $0 \leqq t \leqq T$, for all $i$

(b) $\dot{D}_{i}(t)>0$ for $0 \leqq t \leqq \bar{t}, \dot{D}_{i}(t)=0$ for $\bar{t}<t \leqq T$, for all $i$

上の (4.25) に対応する場合を以後タイプ（a）と呼ぶことにすると,タイプ (a) は都市が計 画期間中ずっと成長し続ける場合に相当する。これに対して，(4.26）の場合をタイプ (b) と 呼ぶことにすると，タイプ (b) は都市の成長が計画期間の途中で止まる場合に相当する。

まずタイプ（a）の場合の最適拡大過程について調べう。この場合の各建設スイッチ時刻 
$t_{i l}{ }^{*}$ は図 4 より決定される。この図において, (4.21) で定義される曲線は, (4.25) より, 垂 直や水平部分を持たないなめらかな曲線となる。ところで, 各地区に建設される各施設の量 $\Delta D_{i l}$ は $t_{i l} *$ を用いて，いずれの場合においても次のよらに与えられる。

$$
\Delta D_{i l}=D_{i}\left(t_{i l}{ }^{*}\right)-D_{i}\left(t_{i l-1}^{*}\right)=\int_{t_{i l-1^{*}}}^{t_{i l^{*}}} \dot{D}_{i}(t) d t
$$

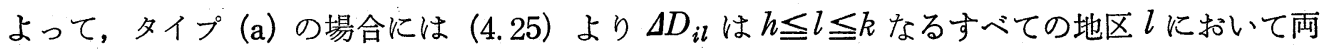
施設とも正であるから，その都市空間の拡大過程は図 6 の（a）のように表わせる。この図にお

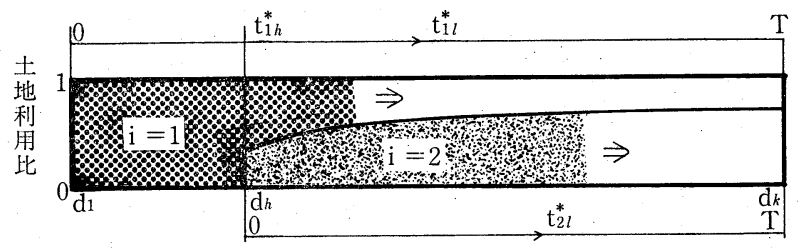

(a) $\quad \dot{D}_{1}(t)>0, \quad \dot{D}_{2}(t)>0$ for $0 \leqq t \leqq T$

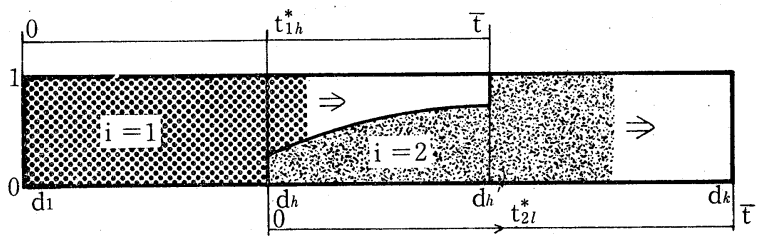

(b-1) $\quad \dot{D}_{1}(t), \quad \dot{D}_{2}(t)>0$ for $0 \leqq t \leqq \bar{t},=0$ for $\bar{t} \leqq t \leqq T$

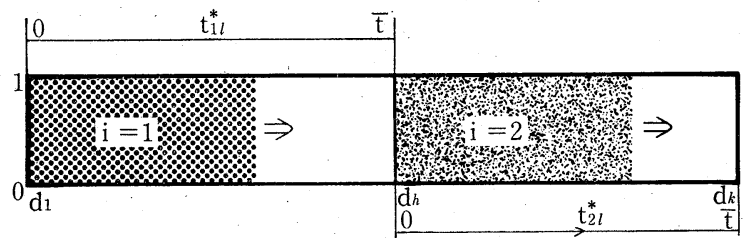

$(b-2):(b-1)$ そ同じ

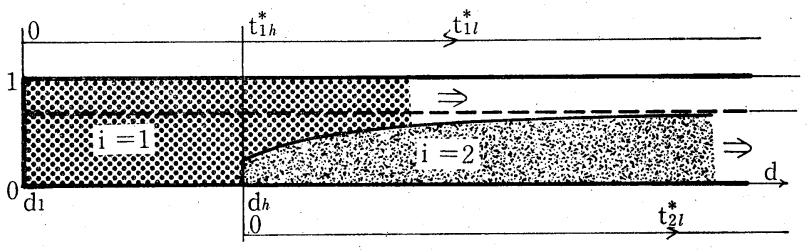

(c) $\dot{D}_{1}(t), \dot{D}_{2}(t)>0$ for $0 \leqq t \leqq \infty$

図 6 都市空間の拡大過程 $(m=2)$

いて横軸は各地区の都心からの距離（：この図では連続的にとってある）であり，縦軸は各地 区に括ける二施設間の土地利用比率である。この図からも明らかなように， $i=2$ は常に $i=1$ 
よりもずっと郊外において建設されて行き，両施設が同一地区において同時に建設されること はありえない。ただし，結果的には地区 $h$ 以遠では両施設は混在となる。また，図 7 の (a) は この拡大過程の 1 時刻に拈ける平面形状を, 都心からの距離がどの方向にも一様に増加する場 合について描いたものである（：よって，方向による交通条件の違いは考えていない)。ただ しこの図において, 都心から半径 $d_{h}$ 以上の地区において各施設は適当に 8 万向にまとめてあ るが，これは異施設混在による外部負効果を避けるために問題と関係なく著者が勝手にゾーニ ング分けしたものであり，このようなゾーニング指定を行なわない場合には両施設は $d_{h}$ 以上 で完全に混在となる。

次に（4.26）の場合であるが，この場合の都市空間の拡大形状は基本的に二つの異なったタ イプに分かれる。ひとつのタイプの拡大過程は図 6 の（b-1）のように図示でき（以下これをタ イプ (b-1) と呼ぶ)，もらひとつのタイプは図 6 の (b-2) に示してある（これをタイプ (b-2) と呼ぶ)。タイプ (b-1) の場合には, $i=2$ は都心からある距離 $d_{h}$ の地点から建設されはじめ, その後各地区の 1 部に建設されて行くが，ある距離 $d_{h^{\prime}}$ 以後に拉いては各地区をすべてうめつ くして行く。よって, 地区 $h$ と $h^{\prime}$ の間でのみ両施設は混在となる。この拡大過程の 1 時刻に 括ける平面形状を描いたのが図 7 の (b-1) である。このタイプ (b-1) は, 都市が比較的長期

(a)

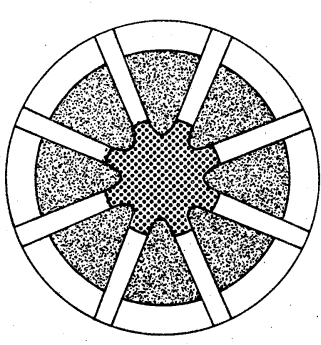

$(b-2)$

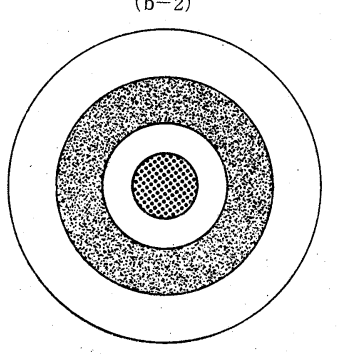

$(b-1)$

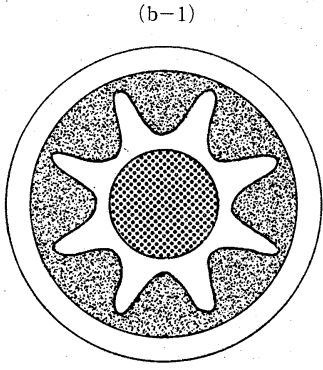

(c)

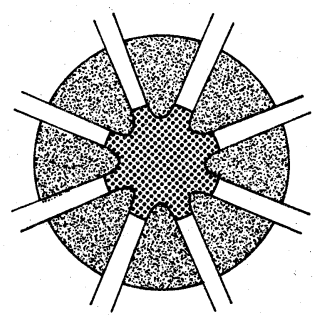

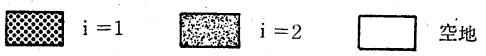

図 7 都市空間拡大過程の平面形状 $(m=2)$

(a), (b-1) (b-2) (c) 
にわたって成長して行くが，ある時点で成長がストップする場合に起る。

それに対してタイプ (b-2) の場合には， $i=2$ は最初から地区 $h$ 以遠の各地区をすべてらめ つくしながら建設されて行く。よって両施設の混在は一切起らない。ただし，この場合の地区 hは（4.20）でなしに, 次の関係をみたす地区である。

$$
\sum_{l=1}^{h-1} s_{l}<k_{1} D_{1}(\bar{t}) \leqq \sum_{l=1}^{h} s_{l}
$$

この場合の都市空間の時刻 $\bar{t}$ 以降の形状は，すべての施設量 $D_{1}(\bar{t})$ および $D_{2}(\bar{t})$ を 1 時刻に おいて一瞬に最適配置するといら，時間を考えない静的な最適配置と一致している。つまり各

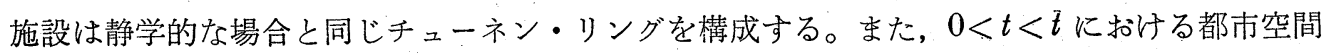
の平面形状は図 7 の (b-2) のように描ける。このタイプ (b-2) は, 一定規模の都市を比較的 短期間に完成し，以後長期にわたって使用されるという場合に相当する。

タ.イプ (b-1) あるいは（b-2) のどちらになるかは図4 と同様の図を描くことにより簡単に 決定できる。ただし（4.26）のもとでは各面積曲線（4.21）は図8の（b-1）あるいは (b-2) のように, 時刻 $\bar{t}$ 以後では水平ないし垂直となる。これらの図において直線（4.22）を描いた
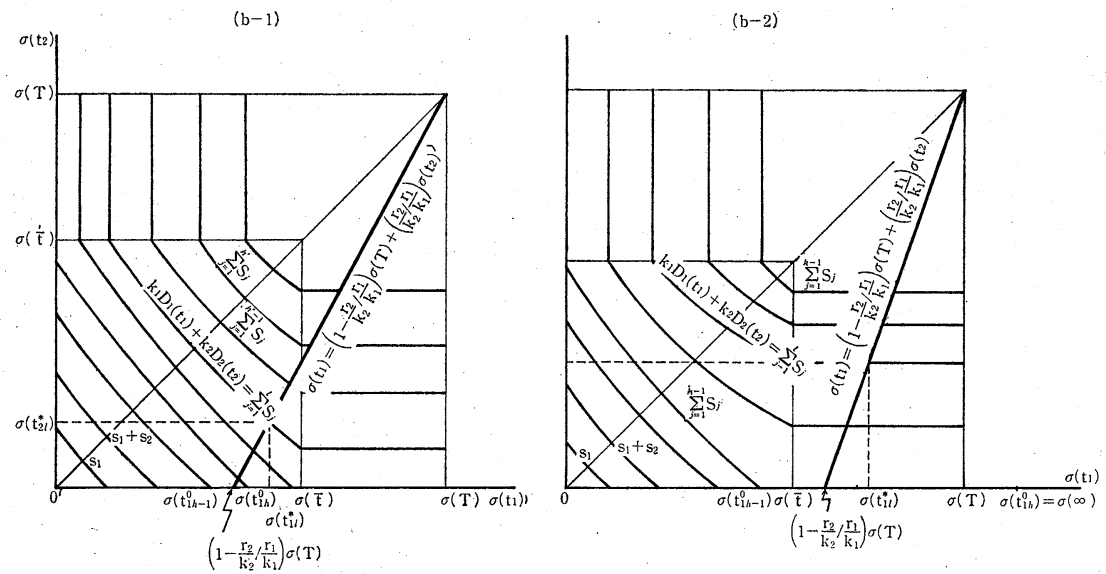

図 8 一定規模の都市を比較的短期間に完成する場合の $t_{i l}$ * の決定 $(b-1), \quad(b-2)$

とき,この直線と横軸との切片 $\left(1-\frac{r_{2}}{k_{2}} / \frac{r_{1}}{k_{1}}\right) \sigma(T)$ が図 8·(b-1) のように $\sigma(\bar{t})$ の左側に ある時はタイプ (b-1) となり，図 8·(b-2) のように $\sigma(\bar{t})$ の右側にくればタイプ (b-2) とな る。これより，Tに比して $\bar{t}$ が非常に小さい時は必ずタイプ $(\mathrm{b}-2)$ となることがわかる。ま た,これらの図から, 両施設の混在のはじまる地区 $h$ や終る地区 $h^{\prime}$, 各建設スイッチ時刻は 容易に読みとれる。

ところで, 以上の議諭においてはすべて計画期間 $T$ の長さは有限と仮定していたが， $T$ が 
無限大の場合においても問題 A の解は常識的な仮定のもとでは常に存在する11)。その場合, $T=\infty$ の時の解は，以上のすべての式において $T=\infty$ と代入すればそのまま得られる。たと えば (4.25)，つまりパターン（a）に拈いて $T=\infty$ の時の拡大過程は図 6 の (c) のように描け る。 $i=2$ は常に $i=1$ よりもずっと郊外に建設されながら都市空間は拡大して行く。またこ の場合の都市空間の 1 時刻における 3 平面形状を描いたのが図 7 の (c) である。

なお，(4.20) より, パターン（a）の場合には $i=2$ の最初に建設されはじめる地区 $h$ は, 計画期間の長さ $T$ が大きいほど都心から遠くになり，便益の減少勾配 $\frac{r_{i}}{k_{i}}$ の両施設間におけ る差が大きいほど遠くになり，空地の存在する期間も長くなることがわかる。

\section{IV-3 地価曲線の時間的変化}

つぎに最適拡大過程に供なった補助変数 $p_{i}(t)$ つまり各地区の（割引された）地価の変化に ついて調ベてみよう。

各地区の地価 $p_{l}(t)$ の時間的変化は (4.23) で与えられ，これを横軸に $\sigma(t)$ をとって描け ば図 5 のようになることはそこで述べた。ここでは, 一時刻における各地区にお杍る地価 $p_{l}(t)$ を空間的に連らねたものを地価曲線と呼ぶことにし，その変化について見てみよう。まず仮定 (4.25), つまりパターン (a) の拡大過程にともなら地価曲線 $p_{l}(t)$ の変化は, (4.23) と (4.24)

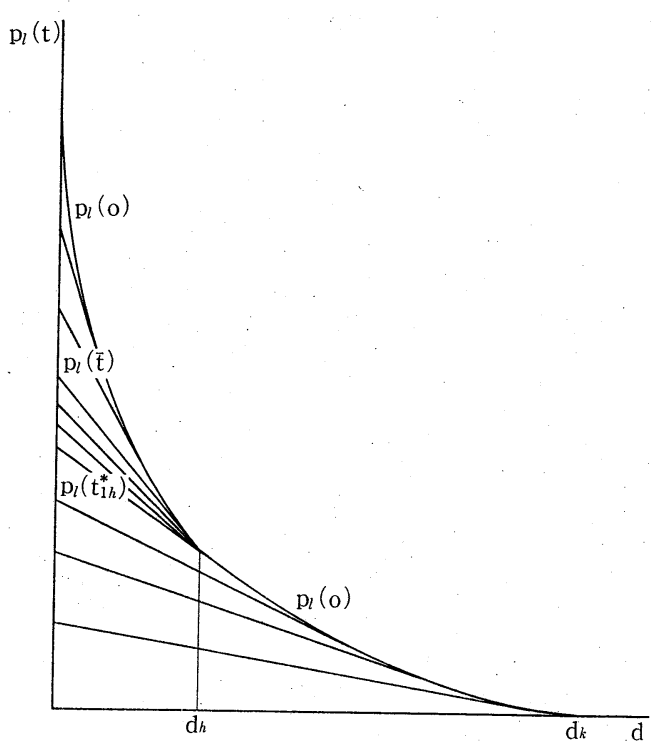

図 9 地価曲線 $p_{l}(t)$ の時間的変化 (パターン (a), (b-1))

より図 9 のように描ける。まず, 初期時刻 $t=0$ における地価曲線 $p_{l}(t)$ は図に打ける ように, 強く下に凸の曲線となっている。 つぎに，たとえば時刻 $t=t_{1 j}{ }^{*}$ においては $i=1$ は地区 $j$ まで建設されているが，こ の時の地価曲線 $p_{l}\left(t_{1 j}{ }^{*}\right)$ は図におけるよう に, 地区 $j$ より郊外側に执いては $p_{l}\left(t_{1 j}{ }^{*}\right)$ $=p_{l}(0)$ であり, 都心と地区 $j$ の間は曲線 $p_{l}(0)$ に地区 $j$ で接する直線となっている。 同様に, この直線部分が $i=1$ の建設地区 の移動とともに，その建設地区を中心とし た時間的回転速度 $-\rho(t)\left(r_{1} / k_{1}\right)$ でその勾 配を減少させながら，除々に郊外へと初期 地価曲線に沿って延びて行く。

仮定（4.26）の場合でも，タイプ (b-1)

11）たとえば次の条件のもとに解は存在する。 $\sigma(\infty)<\infty, \sum_{l=1}^{k-1} S_{l}<\sum_{i} k_{i} D_{i}(\infty) \leqq \sum_{l=1}^{k} S_{l}$ なる地区 $k$ の都 心からの距離は有限である, $B_{i}(\infty)<\infty$ 。最初の条件は，たとえば $\rho(t)$ が負の指数関数の時みたされる。 


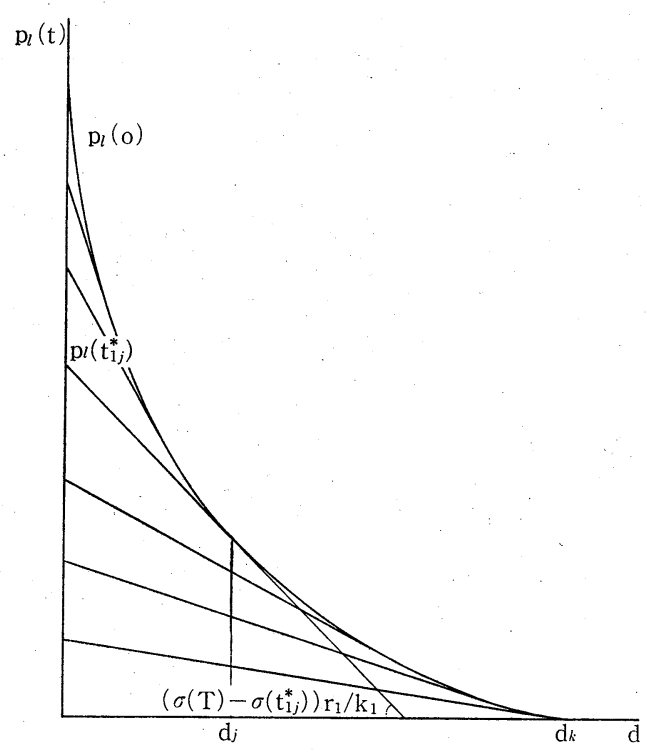

囝 10 地価曲線 $p_{l}(t)$ の時間的変化 (パターン (b-2))

の時はその最適拡大過程に沿った地価曲線の変化はタイプ（a）の場合と本質的には同じであ り,やはり図9のように描ける。ただしタイプ（b-2）の時は少し異なってくる。まず，初期地 価曲線 $p_{l}(0)$ は図 10 に拈けるように, 図 6 の (b-2) に対応する地区 $h$ で折れ曲っている。 $p_{l}(0)$ の地区 $h$ に抢ける左側接線の勾配は $\left(r_{1} / k_{1}\right)(\sigma(T)-\sigma(\bar{t}))$ であるのに対して, 右側接線 の勾配は $\left(r_{1} / k_{2}\right) \sigma(T)$ であるが，図 $8(\mathrm{~b}-2)$ からわかるよらに $\sigma(\bar{t})<\left(1-\frac{r_{2}}{k_{2}} / \frac{r_{1}}{k_{1}}\right) \sigma(T)$ であるから, 左側の勾配の方が大きい, 従って, 地価曲線の時間的変化は, 直線部分が地区 $h$ まで延びたのち，しばらくはこの地区に止まって拈り， $\left(r_{1} / k_{1}\right)\left(\sigma(T)-\sigma\left(t_{1 h}{ }^{*}\right)\right)=\left(r_{2} / k_{2}\right) \sigma(T)$ となる時刻 $t_{1 \text { h }}{ }^{*}$ において再び動きはじめる。

なお，各時刻，各地区に拈ける各施設 1 単位供給にともなら将来利潤（の $t=0$ に割引かれ た值） $\pi_{i l}(t)$ は, (3.15) より次式のようになる。

$$
\pi_{i l}(t)=\phi_{i l}(t)+q_{i}(t)-\rho(t) b_{i}(t)-k_{i} p_{l}(t)
$$

最適拡大過程にともなら, この建設利潤 $\pi_{i l}(t)$ の変化を示したものが図 11 である。 時刻 $t$ において施設 $i$ が建設されている地 区を $l_{i}(t)$ で表わし，これをその施設の建 設限界地区と呼ぶことにする。そうする と, $i=2$ の建設利潤 $\pi_{i l}(t)$ はその限界地 区でちようどゼロであり，その他のすべて

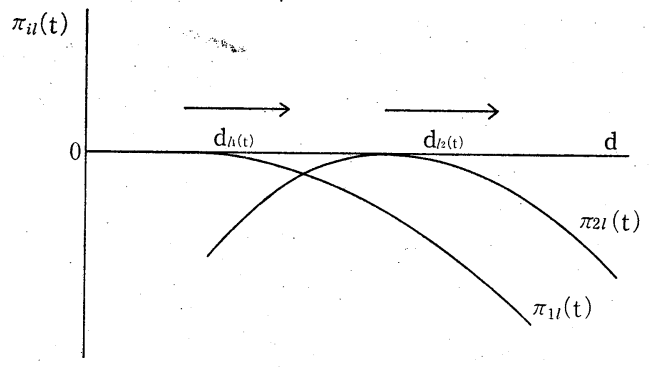

図 11 建設利潤 $\pi_{i l}(t)$ と限界地区の移動 
の地区に抢いては負となっている。一方， $i=1$ の建設利潤 $\pi_{i l}(t)$ は，その施設の限界地区 $l_{1}(t)$ と都心との間ではゼロであり，その他の地区ではすべて負となる。これら，利潤ゼロの 地点が，各建設限界地の移動とともに郊外に移行してゆく。

ところで，以上に拈いては施設の供給のために建設業者が必要な土地を購入すると仮定した が，そのかわりに，必要な土地は各地区の地主から借りるものと仮定すると各時刻に拈いて地 主に地代が支払われることになる。この（割引かれないもとのままの）均衡地代を $R_{l}(t)$ と拈 くと，完全競争のもとに抢ける均衡径路の上においては，この地代 $R_{l}(t)$ と地価 $p_{l}(t)$ とは次 の関係にあるのは明らかである。

$$
p_{l}(t)=\int_{t}^{T} \rho(\tau) R_{l}(\tau) d \tau
$$

両辺を微分して，地価の変化と地代との関係を与える次式を得る。

$$
\dot{p}_{l}(t)=-\dot{\rho}(t) R_{l}(t)
$$

したがって, (4.23) と（4.31）より，地下 $R_{l}(t)$ は次のように求まる。

$$
R_{l}(t)=\left\{\begin{array}{l}
0 \text { for } t<t_{1}{ }^{*} \\
\left(r_{1} / k_{1}\right)\left(d_{j}-d_{l}\right) \text { for } t_{1 j-1}{ }^{*} \leqq t \leqq t_{1 j} *, j=l+1, l+2, \cdots, k-1
\end{array}\right.
$$

各地区の各時刻に括ける施設レントは $\left(B_{i}(t)-r_{i} d_{l}\right)$ であるから，上式より，各地区の地代 は, 面積当りレントの減少勾配 $v_{i} / k_{i}$ の最も大きい $i=1$ のその時刻における建設地区の施設単 位面積当りレントと，各地区に打けるそれとの差に等しいことがわかる。このことは図 5 から 尤，また図 9 と図 10 からも読みとれる。以上のように，地価や地代の変化に拈いては，面積 当り施設便益（ニレント）の距離に対する減少勾配の最も大きい $i=1$ の動きが中心的役割を 持っていることがわかる。

以上においては, 初期時刻 $t=0$ に割引かれた地価 $p_{l}(t)$ の変化について見たが，最後にも との（割引かれない）地価 $P_{l}(t)$ の変化について調べてみよう。そのために，Tと $T(t)$ につ いて次のように仮定しておく12)。

$$
\begin{gathered}
T=\infty \\
\rho(t)=e^{-\beta t}, \beta>0
\end{gathered}
$$

まず, (3.14) より $P_{l}(t)$ は $p_{l}(t)$ から次式のように求まる。

$$
P_{l}(t)=p_{l}(t) / \rho(t)
$$

(4.31)，(4.33)，(4.34）および (4.35) より次の関係をらる。

$$
\dot{P}_{l}(t)=\beta P_{l}(t)-R_{l}(t)
$$

12）以下のように，計画期間の大きさを無限大とし，割引率を時間的に一定とすることは，最適計画問題そ のものの論理的完結性や，均衡径路における予測の実現性といいうことから必要となる仮定である。こ のことについては，文献 [5] の第 4 節を参照。 
さらに（4.23），(4.35）と上式を用いて次の関係もらることができる。

$$
\partial \dot{P}_{l}(t) / \partial d_{l}=-r_{1} / k_{1}-\partial R_{l}(t) / \partial d_{l}
$$

よって，(4.32）と（4.35）より，i=1 がその地区に建設されるまでは（つまり，その地区 に空地がなくなるまでは), 各地区の地価 $P_{l}(t)$ は各時刻において割引率 $\beta$ の割合で上梨し, 空地のなくなった以後は，地価の上梨率はその地区の地代の值だけ鈍ることがわかる。また， (4.32) と（4.36）より，i=1 の建設されている地区（つまり，i=1 のその時刻に拈ける建設

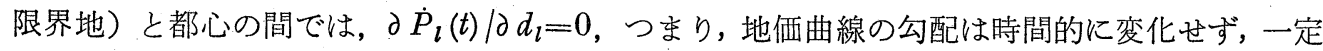
勾配 $\left(r_{1} / k_{1}\right) / \beta$ を持った直線であることがわかる。よって，地価曲線 $P_{l}(t)$ の時間的变化は図 12 のように描ける。ただしこの図は, 都市施設の終局的な拡大が都心より有限な距離 $d_{k}$ で停

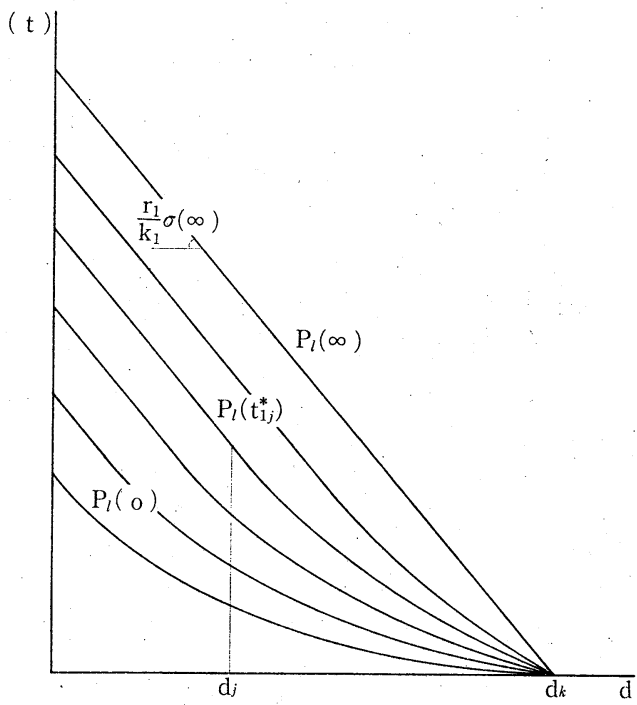

図 12 地価曲線 $p_{l}(t)$ の時間的変化

止する場合であり，もしも都市が永久に拡大を有限大の速度で続けるならば，この図の $d_{k}$ は 無限に右側となり， $P_{l}(\infty)$ なる漸近線は存在しないで， $P_{l}(t)$ は永久に上年を続けることにな る。

\section{V 任意の施設数の場合への一般化}

前節に扔いては施設数が 2 個の場合について問題 $\mathrm{A}$ の最適拡大過程を分析した。本節にお いて，そこでの結果を任意の施設数の場合へ一般化する。ただし，本節の結果はほとんど前節 ででの結果から容易に推測できることなので，説明はなるべく簡単にする。

仮定（2.11） と前節での結果から容易に推測できるように，問題 $\mathrm{A}$ の一般的な最適拡大過 程のパターンは次のようになる。 
（1）単位敷地面積当りの施設便益の距離に対する減少勾配 $\boldsymbol{r}_{i} / k_{i}$ の值の 1 番小さな施設であ る $i=m$ は, 最初に都心からずっと離れたある地区 $h(m-1)$ より建設されはじめ, その後地 区 $h(m-1)+1$ の 1 部, $h(m-1)+2$ の 1 部と, 各地区に大きな空地部分を残しながら時間と ともに順次郊外へとその建設地を移動させて行く。

(2) 施設 $i(1<i<m)$ についても同様であるが，各時刻に打けるとの建設地区は，施設 $i$

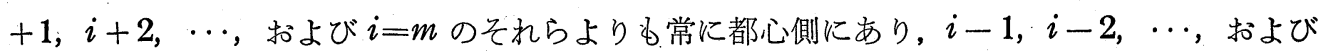
$i=1$ のそれらよりも常に郊外側にある。

(3) 勾配 $r_{i} / k_{i}$ の一番大きい施設である $i=1$ は, 最初都心に一番近い地区 $l=1$ より建設さ れはじめ，その後各施設の建設のあとに残された空地部分を完全にらめつくしながら順次その 建設地を郊外へと移動してて行く。

施設 $i$ と $i+1$ との境界地区, すなわち, 施設 $i+1$ の最初に建設されはじめる地区を $h(i)$ と表わすことにする。そうすると，以上の最適拡大過程を仮定 (4.25) (つまり，パターン (a))

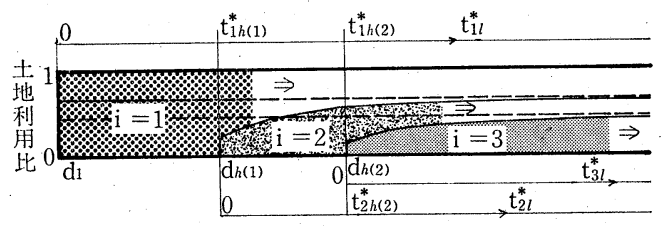

図 13 都市空間の拡大過程 $(m=3)$

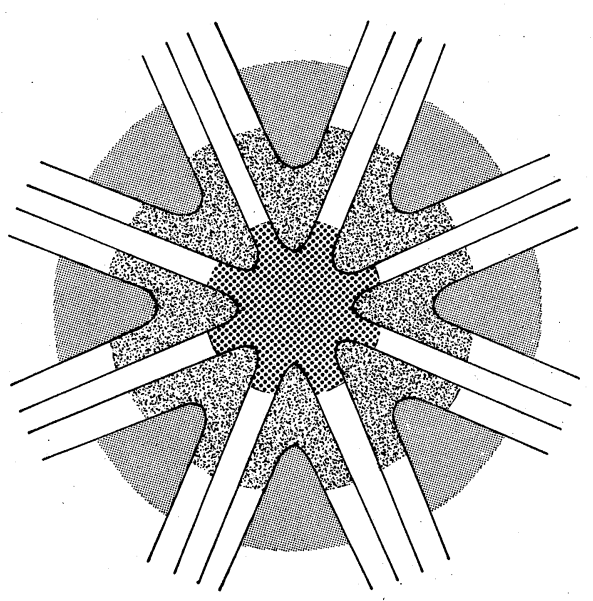

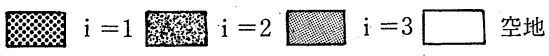
図 14 都市空間拡大過程の平面形状 $(m=3)$
のもとに $m=3$ の場合について描くと図 13 の ようになる。(他のパターンの場合についても 同様に描けるが,ここでは省略する。）また， 図 14 はこの拡大過程の 1 時刻に打ける平面形 状を描いたものである。まえと同様, 各施設は 適当に 8 方向にまとめられている。たとえば, $i=1$ は商・業務用建物で, $i=2$ は高層住宅, $i=3$ は平屋住宅と考えれば適当であろう。こ れらの図からわかるように, 都心から同一の距 離帯上のすべてが同一種類の施設でらめられる のは, 都心と $i=2$ の初期時刻建設地区 $h(1)$ の間のみであり，他の地区ではすべて終局的に は二種類以上の施設の混在となる。 それでは, 各施設 $i$ の最初に建設されはじめ 
る地区 $h(i-1)$ や，その後に施設 $i$ の建設が地区 $l$ から $l+1$ に移る時刻 $t_{i l}$ *を求めてみよう。 まず, $h(0)=1$, つまり $i=1$ の建設されはじめる地区は $l=1$ であることは明らかである。つ ぎに, かりに $i=2$ の建設されはじめる地区 $h(1)$ と $i=3$ のそれ $h(2)$ がわかっているとする。 そうするとその間の地区 $l(h(1) \leqq l<h(2))$ に関しては, (4.17) を得たときと同様にして, 施 設 $i(i=1,2)$ の建設が地区 $l$ から $l+1$ に移る時刻 $t_{i l}{ }^{0}, i=1,2,(: h(1)$ と $h(2)$ が未定で あるので $t_{i l} *$ のかわりに $t_{i l}{ }^{0}$ と書いておく）においては次の関係が成立していることがわか る。

$$
\left(\sigma(T)-\sigma\left(t_{1 l}^{0}\right)\right) r_{1} / k_{1}=\left(\sigma(T)-\sigma\left(t_{2 l}^{0}\right)\right) r_{2} / k_{2}
$$

また，時刻 $t_{1 l}{ }^{0}$ においては都心から地区 $l$ までは $i=1$ と 2 とですべてらめつくされていると いらことから次の関係をらる。

$$
\sum_{i=1}^{2} k_{i} D_{i}\left(t_{i l}{ }^{0}\right)=\sum_{j=1}^{l} s_{j}
$$

よって, $i=2$ の最初に建設されはじめる地区 $h(1)$ は, 二元連立方程式 (5.1), (5.2) が正の 解（つまり $\left.t_{1 l^{0}}, t_{2 l}{ }^{0}>0\right)$ を持つ地区 $l$ のちで一番都心よりの地区として求まる。よって, この $h(1)$ を用いて, $i=1$ が地区 $l$ から $l+1$ に移る時刻 $t_{1 l} *(1 \leqq l<h(1))$ は次式より求まる。

$$
k_{1} D_{1}\left(t_{1 l}^{*}\right)=\sum_{j=1}^{l} s_{j}, \quad 1 \leqq l<h(1)
$$

つぎに，仮に $i=4$ の建設されはじめる地区 $h(3)$ がわかっているとする。そらすると，同 様にして，その間の地区 $l(h(2) \leqq l<h(3))$ に打いて, 施設 $i(1 \leqq i \leqq 3)$ の建設が地区 $l$ か ら $l+1$ に移る時刻 $t_{i l}{ }^{0}$ (: 同様の理由で $t_{i l}{ }^{*}$ のかわりに $t_{i l}{ }^{0}$ と書いておく)にはそれぞれ次の 関係がみたされているはずである。

$$
\begin{gathered}
\left(\sigma(T)-\sigma\left(t_{1 l}^{0}\right)\right) r_{1} / k_{1}=\left(\sigma(T)-\sigma\left(t_{2 l}^{0}\right)\right) r_{2} / k_{2}=\left(\sigma(T)-\sigma\left(t_{3} l^{0}\right)\right) r_{3} / k_{3} \\
\sum_{i=1}^{3} k_{i} D_{i}\left(t_{i l}{ }^{0}\right)=\sum_{j=1}^{l} s_{j}
\end{gathered}
$$

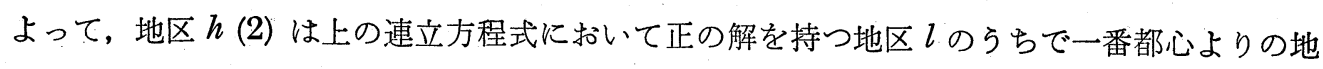
区として求まる。

したがっで,h(1) とh(2) がわかったのであるから，(5.2)，(5.3) を解いて,

$$
t_{i l}{ }^{*}=t_{i l}{ }^{0}, i=1,2, h(1) \leqq l<h(2)
$$

とおくことにより $i=1,2$ のその間における建設スイッチ時刻が定まる。

以下順次同様にして,すべての $h(i-1)$ と $t_{i l}$ *を求めることができ, これらの值を用いて問 題 A の最適拡大過程は一義的に次のように定まる。

$$
u_{i l}(t)=\left\{\begin{array}{l}
\dot{D}_{i}(t), t_{i l-1}{ }^{*} \leqq t<t_{i l}{ }^{*} \\
0, \text { その他の時 }
\end{array} \quad i=1,2, \cdots, m, l=1,2, \cdots, n\right.
$$




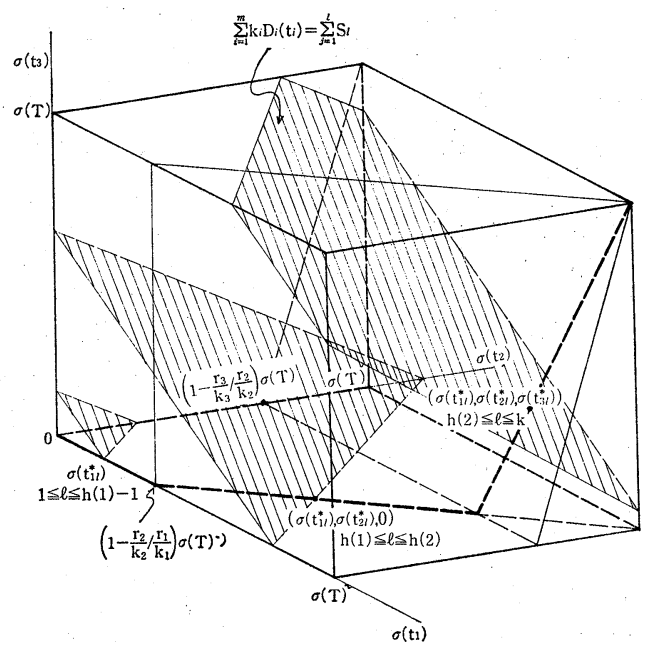

図 15 建設スイッチ時刻 $T_{i l}$ *の決定 $(m=3)$

以上の建設スイッチ時刻 $t_{i l} *$ の決定方法を $m=3$ の上きについて図 4 と同様の手続のる とに描いたものが図 15 である。この図の左 隅において (5.3) そもとづくひとつの $t_{11} *$ の 決定が，中ほどに (5.1) と (5.2)にもとづく ひとつの $\left(t_{11} *, t_{2 l} *\right)$ の決定が，右隅に怙い て (5.4)と (5.5) にもとづくひとつの $\left(t_{12}{ }^{*}\right.$, $\left.t_{2 l} *, t_{3 l}{ }^{*}\right)$ の決定がそれぞれ描かれている。

最後に, この最適拡大過程に対応する地価 曲線 $p_{l}(t)$ の変化は (4.23) と全く同一の式 で表わされる。したがって $i=1$ の建設がそ の地区を通過するまでは，各地区の地洒 $p_{l}$ ( $t$ ）は初期の值の季まであり，(4.32）で表わされているようにそれらの地区において地代は発 生しない。したがって，地洒曲線 $p_{l}(t)$ と $P_{l}(t)$ はそれぞれ以前とほとんど同様に描ける。

\section{VI 結論}

都市が時間とともに成長して行く場合に，長期的に見て最も効率的な施設の空間的・時間的 な配置過程を簡単な数理モデルを用いて分析した。たとえば図 7 は都市空間の最適拡大過程の 各種のパターンを示すが，いずれの場合に执いても，長期的に見て効率的な都市空間は内部に 多くの空地を有しながら拡大して行くことがわかる。このような土地利用は短期的に見机ばき わめて非効率なるのであり，したがって，長期的な土地利用は短期的な計画の繰返しでは決し て実現されない。しかしながらそれら両計画の効率性の差は時間の経過とともにはっきりして 行く。これは, 都市計画に批る「急がば回れ」といらことの重要性を示唆するものであると 言える。つまり以上の分析は, 空間計画に批るいわばひとつのターンパイク定理を提供した 包のと言えるであろう。

ところで，たとえば図 14 に括いて, 施設 3 は都心からのある半径以上においては同一距離 帯内に多くの空地を残しながら郊外に拡大して行き，将来は施設 2 と 1 がその空地を順次らめ て行くことになる。したがって,この図のよらに各施設建設用の土地を前もってジーニング分 けして招かないかぎり，各施設はいわばスプロール的に拡大して行き，打そかれはやかれ各施 設は混在となる。このことは都市利用計画に括ける先見的なゾーニング政策の重要性を示唆し ていると言える。

しかしながら，逆にみなせばこのことは，たと充ば住宅がスプロール的に郊外に広がって行 
くからと言って，必ずしも非常に非効率的な都市の発展形態だと言い切れないといらことを意 味する。このような施設のスプロール的な拡大は均衡市場径路上に打いても起り得て, しかも それはパレート最適性をみたしていることも証明できる13)。もっとも，これらのことは土地利 用計画に括ける先見的なゾーニングの必要性を少しも否定するものではないが。

最後に, このよらな都市空間の最適成長過程を分権的に達成するに用いらる土地価格の経年 変化を図 12 に示しているが，これは静学的な地価理論から得られる結果と全くことなったも のであることがわかる。たとえば初期時刻にはすべての地区は全くの空地であるにもかかわら ず，各地は大きな正の土地価格を持っている。これより, 都市が成長を続けて行く限り, 空地 に高い地価が付き，また効率的な土地利用に対応する土地価格が上算して行くことは全く自然 なことであることがわかる。もしも土地価格が上昇し続けることに問題があるとすれば，それ はその都市がいつまでも拡大し続けて行くこと，および，土地の所有権の問題であろら。

な拈，以上の分析では各時刻における各施設の都市全体での必要量を外生的に与えており， また，都市の 1 点中心の仮定に強く依存しているが，今後は施設間の代替性を考えて各施設の 量の決定をできるだけ内生化し，さらには，都心の発展形態をも問題とした研究がなされるべ きだと考えている。

\section{参考文 献}

[1] Alonso, W., Location and Land Use, Harvard University Press, 1964.

[2] Arrow, K. J. and M. Kurz, Public Investment, the Rate of Return, and Optimal Fiscal Policy, The Johns Hopkins Press, 1970, pp. 26-57.

[3] 藤田昌久, “都市空間の最適成長過程”, 日本地域学会第 10 回大会報告要旨, 1973 年 12 月, pp. 90-109.

４］——“都市施設の長期的最適配置過程関する研究”，土木学会論文報告集，No. 222，1974 年 2 月

[5] —，“都市空間拡大過程の動学分析”，日本交通政策研究会シリーズ A-13-2，1974 年5月

[6]. Hestenes, M.R., Calculus of Variations and Optimal Control Theory, John Wiley \& Sons, Inc., 1965, pp. 352-374.

[7] Kamien, M.I. and Sshwartz, N. L., "Sufficient Conditions in Optimal Control", Journal of Economic Theory, 3, 1971, pp.207-214.

[8] ポントリャーギン他著, 関根智明訳, 「最適過程の数学的理論」, 総合図書, 昭和 42 年, pp. 269-328.

13）この点に関しては文献 [5] を参照。 


\section{Optimal Process of Urban Spatial Growth}

An optimal process of urban spatial growth is studied in this paper. The problem analyzed in this paper is to allocate the total increase of each urban facility, of which total amount for the whole region is given exogenously at each time, among the urban area at each time so as to maximize the total benefit obtained from these facilities over the entire planning periods. It is assumed that each facility in each area cant be moved to other areas once it is constructed. The benefit obtainable from each unit of each facility per each time is assumed to be decreasing linearly from the urban center. The demolition of each facility is ignored.

By using the maximum principle in the optimal control theory, the general solution for this problem is obtained. The land price in each area to sustain this optimal growth is also obtained. 